\title{
Prospects of Using Non-Conventional Fertilizers in the Forest Nurseries for Growing the Planting Stock of Common Pine (Pinus Sylvestris L.)
}

\author{
MS Dyakov ${ }^{1 *}$, SV Zalesov ${ }^{2}$ and YaI Vaisman ${ }^{3}$ \\ ${ }^{1}$ Federal State Budgetary Institution, Ural State Research and Engineering, Russia \\ ${ }^{2}$ Federal State Higher Education Institution, Ural State Forest Engineering University, Russia \\ ${ }^{3}$ Federal State Budgetary Higher Education Institution, Perm National Research University, Russia
}

${ }^{*}$ Corresponding author: MS Dyakov, Federal State Budgetary Institution, Ural State Research and Engineering Institute of Regional Environmental Problems, Russia

\begin{abstract}
The opportunity of using non-conventional composite mixtures as fertilizers for growing one- and two-year seedlings of common pine (Pinus sylvestris L.) was studied in the forest nursery of Sukholozhsky Forest District and Ural Educational and Experimental Forest Farm of the Federal State Higher Education Institution Ural State Forest Engineering University. The composite mixtures were prepared based on the sewage sludge produced by public treatment stations or the products of their thermal processing. Root application of composite mixtures was used with preceding and subsequent soil loosening in the doses of $500 \mathrm{~kg} / \mathrm{ha}$ and 1,000 $\mathrm{kg} / \mathrm{ha}$. After the end of the growing season, 30 seedlings were taken out in each experiment option and their key parameters were measured: stipitate length, root neck diameter, rooting tuft length. The research involved one- and two-year seedlings. The obtained results are of practical importance for the use of sewage sludge newly formed and accumulated in the process of operation of public wastewater treatment facilities.
\end{abstract}

Keywords: Excess Active Sludge; Sewage Sludge; Fertilizers; Seedlings; Forest Nursery; Common Pine; Composition Mixtures; Resource Potential

\section{Introduction}

The search for economically rational and environmentally safe methods of utilization of the accumulated waste of different production facilities and human activity does not lose its importance; moreover, it has gained special significance for the Russian Federation in the past decades. Such waste includes sewage sludge representing the key type of waste produced by public treatment stations intended for protecting natural water bodies from the contaminations with the components of wastewater of communal, industrial and combined origin. The wastewater treatment facilities' sewage sludge is a standalone type of waste accounting in large cities for about one third of the total production and consumption waste. Each year, 4 million tons of sewage sludge are produced in Russia on dry basis. This figure translates into 16 million tons per year at $75 \%$ humidity. According to Global Water Intelligence, in 2017, 83 million tons of sewage sludge was produced in the world on dry basis with $10.7 \%$ growth vs. 2012, amounting to 3.22 million tons in Russia. Taking into account the initial humidity of $98 \%$, the total weight of the world sludge amounts to 4.15 billion tons, of which 100 million tons are produced in Russia [1]. If we determine per capita ratio, it will be on the level of $108 \mathrm{~kg}$ per Russian citizen. It is worth noting that in the cities of Japan this indicator is at the level of $110 \mathrm{~kg}$ [2], in the cities of Sweden - $118 \mathrm{~kg}$ [3], and in the Federative Republic of Germany (in 1990 per one urban citizen) - $73 \mathrm{~kg}$ [4] per person. In Russia, according to G.G. Onischenko, N.V. Rusakova, over 60-80 billion tons of sewage sludge were accumulated in the sludge drying beds [5]. For example, in Ukraine over 0.5 billion tons of sewage sludge are accumulated by the present moment with the total storage area of about 50 sq. $\mathrm{km}$ in the suburban and urban areas [6]. 
In Europe, 10 million tons on dry basis are accumulated at the moment, while for the USA this indicator is 6 million tons; the costs of treatment of the sewage sludge with account of the consumed energy and wages accounts for up to $80 \%$ of the operating costs of a treatment facility depending on their content [7]. The process of treating the surplus activated sludge and sewage sludge follows a standard scheme in the majority of wastewater treatment facilities in the Russian Federation, which is associated with certain technological limits. Whereas the treatment of surplus activated sludge and sewage sludge at their initial high humidity is uneconomic, they are subjected to compacting. Depending on the scheme adopted by the wastewater treatment facility, compaction may apply to the sludge from the primary settling tanks (sewage sludge), secondary settling tanks (surplus activated sludge), mixture of sludge from the primary settling tanks and surplus activated sludge, flotation sludge, sediments and sludge after stabilization. As a rule, sewage sludge and surplus activated sludge are mixed before compacting, and the compacted waste mixture is positioned as the tertiary settling tanks' sludge. The humidity of the compacted sledge mixture is usually 95 - 98\%. After the sludge densifier, the mixture of sewage sludge and surplus activated sludge with the humidity of $95-98 \%$ is sent to the sludge mechanical drying unit. Mechanical drying is preceded by the chemical treatment of the sludge by flocculant application. After the mechanical drying, the sludge is transported to the sludge lagoons. In case of extreme necessity (emergency mode), humid sludge from primary settling tanks may be removed to the primary drying beds. The most widespread method of sewage sludge treatment that has found countrywide use in the Russian Federation consists in the sewage sludge utilization by its placement in the sludge lagoons and/or sludge drying beds, or combined warehousing in the polygons with solid communal waste. The technologies of sediments and surplus activated sludge processing deployed in the Russian Federation are shown in Figure 1.

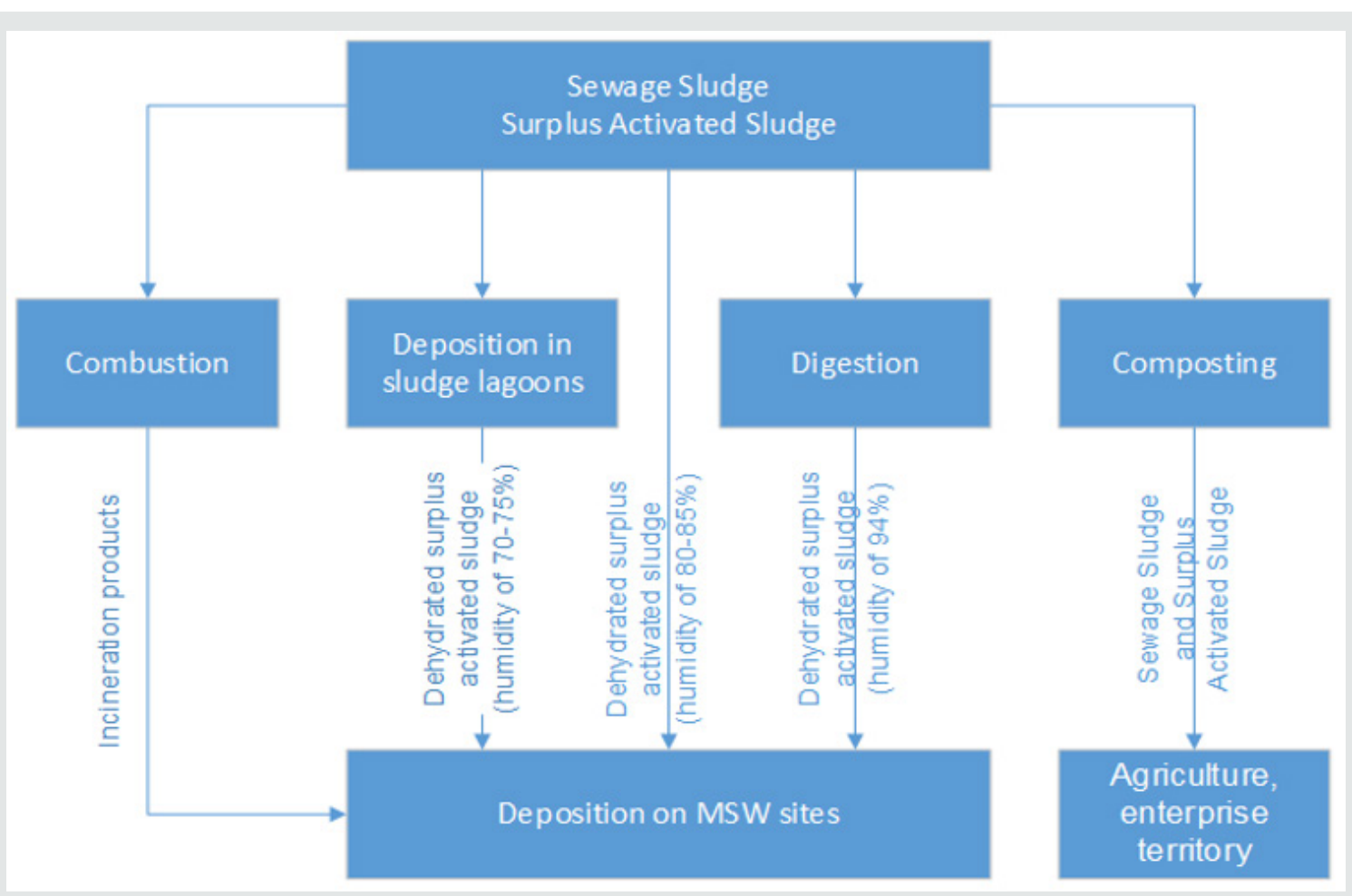

Figure 1: Technologies of Sewage Sludge Processing Deployed in the Russian Federation.

This approach to handling sewage sludge does not meet the current requirements, causing the downtime of land resources, irrecoverable loss of energy potential (calorific value) and resource potential (nitrogen, phosphorus, potassium, humus-like substances), and negative impact on the environment (atmospheric air, soils, surface and groundwater bodies, vegetation, biota). The issue is further complicated by the large amounts of accumulated sewage sludge that were disposed of in the terrestrial environment in different years of the treatment facilities' operation. It should be noted that in different years of operation of the same treatment facilities, different technologies and reagents were used. Also, the process of long-term biodegradation of the waste causes the concentration of heavy metals' ions per unit of waste mass. The implemented technologies of waste incineration cause the formation of ash, which is not used for industrial purposes, but are simply buried in Municipal Solid Waste (MSW) grounds. It is important to look for research-backed and environmentally safe areas for using all of the above wastes.

\section{Materials and Research Methods}

According to the research program, the experiments of studying the effectiveness of applying non-conventional fertilizers for growing the planting stock of the common pine were carried out in Sukholozhsky Forest District and Ural Educational and Experimental Forest Farm of the Federal State Higher Education Institution Ural State Forest Engineering University. The area of the first forest nursery is classified, according to the Forest Zoning Scheme of Sverdlovsk Oblast by B.P. Kolesnikova, R.S. Zubareva 
and E.P. Smolonogova [8], as the area of pre-forest-steppe pine and birch forests, and of the second - as the southern taiga district of Trans-Ural hill and submontane province of West-Siberian Plain forest area.

The research was carried out as a small-scale area experiment $[9,10]$. The fertilizers were applied to the spaces between the sowing rows on $1 \times 1 \mathrm{~m}(1 \mathrm{~m})$ plots. Root application of composite mixtures was used with preceding and subsequent soil loosening. All mixture types were applied in the doses of 500 and 1,000 kg/ ha in the seeding divisions of the forest nursery with one- twoyear seedlings of the common pine during the spring and summer period. After the end of the growing season, 30 seedlings were taken out within the scope of each experiment option and their key parameters were measured: stipitate length, root neck diameter, rooting tuft length. All the information obtained in the course of the research were processed with variation statistics methods in order to determine various average indicators by experiment options and as compared to the reference.

\section{Results}

\section{Component Analysis of the Fresh Wastewater and the Sewage Sludge in the Sludge Lagoons of 1-2 Years And 8-10 Years}

The analysis of components of the newly formed and accumulated wastewater sludge and activated sludge, and incinerated sludge ash or their mixtures (Table 1) was carried out to determine the promising fields of their use. From the information provided in Table 1, it can be seen that the sewage sludge contains heavy metals, which accumulate in the process of wastewater treatment by public treatment facilities. The sewage sludge contains the following elements, such as phosphorus, nitrogen, potassium, humus, calcium. These components are necessary for the plants, improving the crop productivity and depleted soils' contamination. In certain cases, small amounts of heavy metals (micro doses) may have a positive effect on the soil fertility. The excess of heavy metals, in its turn, can move from the soil layer or sewage sludge up the biological chain: humus - plant - animal - human. This fact poses certain danger to the humans. In this regard, the use of sewage sludge as food for agricultural crops or as an organic fertilizer is undesirable. This aspect is associated with high risk of contamination with hazardous substances of soil, plants, ground and surface waters, and possible diseases. The consequences of sewage sludge application are hard to assess even if the sludge is used in relatively small quantities. It should be noted that new degradation products are continuously found in the sewage sludge, such as those of pharmaceuticals. It should further be noted that in the process of biodegradation of the sewage sludge in the places of their deposition, the following processes involving heavy metals, are observed: concentration of heavy metals' ions in a unit of mass of the sewage sludge (1-2 year of deposition) as the organic component degrades, then the washing-out of heavy metals under the effect of rain and melt waters and stabilization of concentration. This explains the fact that by the moment of 8-10 years of sewage sludge storage, the concentration of heavy metals is reduced insignificantly.

Table 1: Component Composition of Fresh Wastewater and Wastewater Deposited in the Sludge Lagoons as well as Sewage Sludge Incinerated Sludge Ash.

\begin{tabular}{|c|c|c|c|c|c|c|}
\hline & & & & & & \\
\hline Measured para & & $\begin{array}{c}\text { Unit of } \\
\text { measurement }\end{array}$ & Fresh Sewage & Sewage Sludge & Sewage Sludge & Incinerated Fresh \\
\hline 1. Ignition losses, $900 \mathrm{C} 0$ & & $\%$ & Over 50 (66.76) & Over 50 (64.34) & $25.4 \pm 0.4$ & $1.74 \pm 0.28$ \\
\hline 2. Aluminium & $\mathrm{AI}$ & $\mathrm{mg} / \mathrm{kg}$ & 12,700 & 13,540 & 10,650 & 73,490 \\
\hline 3. Ferrum & $\mathrm{Fe}$ & $\mathrm{mg} / \mathrm{kg}$ & 20,290 & 22,190 & 17,780 & 58,050 \\
\hline 4. Potassium & $\mathrm{K}$ & $\mathrm{mg} / \mathrm{kg}$ & 4,120 & 5,590 & 4,100 & 23,550 \\
\hline 5. Calcium & $\mathrm{Ca}$ & $\mathrm{mg} / \mathrm{kg}$ & 53,170 & 68,360 & 151,000 & 54,220 \\
\hline 6. Silicon & $\mathrm{Si}$ & $\mathrm{mg} / \mathrm{kg}$ & 57,430 & 58,740 & 210,280 & 233,340 \\
\hline Magnesium & $\mathrm{Mg}$ & $\mathrm{mg} / \mathrm{kg}$ & 8,160 & 7,930 & 5,280 & 16,860 \\
\hline 8. Manganese & $\mathrm{Mn}$ & $\mathrm{mg} / \mathrm{kg}$ & 2,140 & 2,130 & 2,420 & 17,070 \\
\hline 9. Sodium & $\mathrm{Na}$ & $\mathrm{mg} / \mathrm{kg}$ & 1,360 & 1,320 & 890 & 6,360 \\
\hline 10. Titanium & $\mathrm{Ti}$ & $\mathrm{mg} / \mathrm{kg}$ & 13,340 & 10,280 & 5,750 & 36,350 \\
\hline 11. Phosphorus & $\mathrm{P}$ & $\mathrm{mg} / \mathrm{kg}$ & 10,800 & 11,520 & 10,650 & 3,560 \\
\hline 12. Nitrogen & $\mathrm{N}$ & $\mathrm{mg} / \mathrm{kg}$ & 9,310 & 6,776 & 3,042 & - \\
\hline 13. Sulfur & $\mathrm{S}$ & $\mathrm{mg} / \mathrm{kg}$ & 12,700 & 13,540 & 17,780 & 73,490 \\
\hline 14. $\mathrm{pH}$ water extract & & $\mathrm{pH}$ units & $6,61 \pm 0,10$ & $6.92 \pm 0.10$ & $8.15 \pm 0.10$ & $10.68 \pm 0.10$ \\
\hline 15. Mobile potassium & & $\mathrm{mg} / \mathrm{kg}$ & $1,230 \pm 130$ & $1,000 \pm 100$ & $105 \pm 11$ & $390 \pm 40$ \\
\hline 16. Mobile phosphorus & & $\mathrm{mg} / \mathrm{kg}$ & Over $250(1,600)$ & Over $250(1,500)$ & Over $250(570)$ & Over $250(260)$ \\
\hline 17. Mobile cobalt & & $\mathrm{mg} / \mathrm{kg}$ & $8 \pm 3$ & $8 \pm 3$ & $5.3 \pm 2.2$ & $72 \pm 29$ \\
\hline 18. Mobile molybdenun & & $\mathrm{mg} / \mathrm{kg}$ & $2.7 \pm 1.1$ & $1.2 \pm 0.5$ & less than 0.1 & $9 \pm 4$ \\
\hline
\end{tabular}




\begin{tabular}{|ll|c|c|c|c|c|}
\hline 19. & Hydrolytic acidity & $\mathrm{mmol} / 100 \mathrm{~g}$ & less than 0.2 & less than 0.2 & less than 0.2 & less than 0.2 \\
\hline 20. & Organic substance (humus) & $\%$ & Over $15(49.4)$ & Over $15(46.2)$ & $7.8 \pm 0.8$ & less than $1(0.74)$ \\
\hline 21. & Exchange acidity & $\mathrm{mmol} / 100 \mathrm{~g}$ & 1.6 & 2.2 & less than 0.05 & less than 0.05 \\
\hline 22. & Mobile calcium & $\mathrm{mg} / \mathrm{kg}$ & $1,360 \pm 110$ & $1,545 \pm 120$ & $2,060 \pm 160$ & $2,730 \pm 210$ \\
\hline 23. & Mobile magnesium & $\mathrm{mg} / \mathrm{kg}$ & $253 \pm 19$ & $287 \pm 22$ & $372 \pm 28$ & $56 \pm 6$ \\
\hline
\end{tabular}

A negative moment is that a significant part of the underground water budget is the infiltrate of the sludge lagoons contaminated with heavy metals. High content of heavy metals may be traced in several geological horizons. The comparative analysis has shown that the concentration of pollutants in the industrial sites' infiltrate in some cases exceeds twice their content in the groundwater and sludge lagoons' infiltrate. This is indicative of the difficulties associated with the assessment of the negative impact on the soils of extractive heavy metals and other pollutants (from activated sludge and sewage sludge) released with the infiltrate, which requires a more detailed approach to solving the issue with the impact on the environment of the sludge lagoons, especially with a long term of deposition. The analysis of the received information allowed the authors to determine future areas for the research, and, in particular, how to use the sewage sludge of the public treatment facilities and incinerated sludge ash to produce organic and mineral fertilizers in reforestation efforts.

\section{Use of Unconventional Fertilizers in the Reforestation Works}

In the forest nurseries, the process of growing the planting stock is associated with a release on the annual basis of a large number of elements from the upper plowing horizon due to the following factors: consumption of the seedlings' root systems during their growth, degradation of microorganisms in the soil, partial washing out in the lower horizons, release by the seeds, removal of the plowing horizon during the taking out of seedlings [11-15]. Removal of nutrients from 1 ha of common pine crops includes $106 \mathrm{~kg}$ of nitrogen $(\mathrm{N}), 22.3 \mathrm{~kg}$ of phosphorus (P), $53.26 \mathrm{~kg}$ of potassium (K) [16]. The literature on the matter contains the information that the production of $1 \mathrm{~g}$ of dry substance in case of growing forest trees in the open ground requires $20 \mathrm{mg}$ of nitrogen, $25 \mathrm{mg}$ of phosphorus and $15 \mathrm{mg}$ of potassium [17]. Thus, the recovery and improvement of soil fertility in the forest nurseries is provided for by the use of organic fertilizers, growing of green manures and the use of mineral fertilizers. The effect of the fertilizers primarily depends on their doses and the content of nitrogen, phosphorus and potassium in the nutritional medium.

The sewage sludge may be used to satisfy a part of the forest nurseries' need in the nutrients. Also, the sludge improves the humus balance due to high organic content. The use of sewage sludge as a fertilizer is allowed only after the preliminary soil research. For these purposes, the research of soil in two forest nurseries was performed.

a. Sukholozhsky Forest District forest nursery;

b. Ural Educational and Experimental Forest Farm of Ural State Forest Engineering University;

The research results are provided in Tables $2 \& 3$.

According to Table 2, it may be concluded that by the mobile forms of potassium of soil sample I Reg. No. 379 and II Reg. No. 380, the soil can be classified as having medium supply, by nitrogen as having increased supply, and by phosphorus - as having very low supply. On the other hand, soil samples III Reg. No. 381 and IV Reg. No. 382 feature increased potassium supply, very high nitrogen supply and very low phosphorus supply. Whereas, the soil samples were taken at various areas of Ural Educational and Experimental Forest Farm, the plots with insufficient content of the following components were selected for the experiment: humus, nitrogen, mobile forms of potassium and nitrogen. Such plots include the plots, at which soil samples I Reg. No. 379 and II Reg. No. 380 were taken. Whereas, high supply of nitrogen was identified, the soil liming is reasonable.

Table 2: Results of Analytical Research of the Soil Samples, collected in Sukholozhsky Forest Nursery.

\begin{tabular}{|c|c|c|c|c|c|c|}
\hline $\begin{array}{l}\text { Measured } \\
\text { parameter }\end{array}$ & RD for $M^{*} *$ & $\begin{array}{c}\text { Unit of } \\
\text { measurement }\end{array}$ & $\begin{array}{c}\text { Sample I } \\
\text { Reg. No. } 379\end{array}$ & $\begin{array}{c}\text { Sample II } \\
\text { Reg. No. } 380\end{array}$ & $\begin{array}{c}\text { Sample III } \\
\text { Reg. No. } 381\end{array}$ & $\begin{array}{c}\text { Sample IV } \\
\text { Reg. No. } 382\end{array}$ \\
\hline Hydrolytic acidity & GOST** 26121-91 & $\mathrm{mmol} / 100 \mathrm{~g}$ & 0.88 & 0.96 & 5.76 & 12.51 \\
\hline $\begin{array}{l}\text { Organic substance } \\
\text { (humus) }\end{array}$ & GOST 26213-91 & $\%$ & 1.6 & 1.62 & 11.42 & 24.5 \\
\hline Exchange acidity & GOST 26484-85 & $\mathrm{mmol} / 100 \mathrm{~g}$ & 0.055 & 0.055 & 0.06 & 0.065 \\
\hline \multicolumn{7}{|c|}{ Gross content } \\
\hline Nitrogen & GOST 26107-84 & $\mathrm{mg} / \mathrm{kg}$ & 67.4 & 62.3 & 43.4 & 61.4 \\
\hline Phosphorus & \multirow{5}{*}{$\begin{array}{c}\mathrm{CRDF}^{* * *} \\
16.1: 2: 3: 3.11-98\end{array}$} & $\mathrm{mg} / \mathrm{kg}$ & 168 & 215 & 498 & 574 \\
\hline Potassium & & $\mathrm{mg} / \mathrm{kg}$ & 13,480 & 13,940 & 9,569 & 7,782 \\
\hline Sulfur & & $\mathrm{mg} / \mathrm{kg}$ & 735 & 636 & 4701 & 2659 \\
\hline Cobalt & & $\mathrm{mg} / \mathrm{kg}$ & 10.4 & 13.2 & 20.9 & 16.1 \\
\hline Molybden & & $\mathrm{mg} / \mathrm{kg}$ & $<0.1$ & $<0.1$ & 0.26 & 1.18 \\
\hline
\end{tabular}




\begin{tabular}{|c|c|c|c|c|c|c|}
\hline \multicolumn{7}{|c|}{ Water extract analysis } \\
\hline Hydrogen index & GOST 26423-85 & pH units & 6.33 & 6.52 & 5.46 & 5.48 \\
\hline \multicolumn{7}{|c|}{ Mobile forms } \\
\hline Potassium & \multirow{4}{*}{$\begin{array}{c}\text { CRDF } \\
16.1: 2: 3: 3.50-08\end{array}$} & $\mathrm{mg} / \mathrm{kg}$ & 82 & 95 & 140 & 177 \\
\hline Phosphorus & & $\mathrm{mg} / \mathrm{kg}$ & 15.5 & 18.6 & 17.3 & 26.7 \\
\hline Calcium & & $\mathrm{mg} / \mathrm{kg}$ & 320 & 339 & 742 & 930 \\
\hline Magnesium & & $\mathrm{mg} / \mathrm{kg}$ & 51 & 71 & 95 & 128 \\
\hline
\end{tabular}

*RD for MP - Regulatory Documents for the Measurement Procedure

**GOST - Russian State Standard

***CRDF - Conservation Regulatory Document Federative

According to (Table 3), it may be concluded that by mobile forms of potassium soil sample I Reg. No. 388 is classified as having low supply, by nitrogen - as having very high supply, and by phosphorus - having low supply. On the other hand, soil samples III Reg. No. 389, III Reg. No. 390, IV Reg. No. 391 and V Reg. No. 392 feature increased potassium supply, very high nitrogen supply and very low phosphorus supply. T soil samples were also taken at various areas of Sukholozhsky Forest Nursery, therefore, the plots with insufficient content of the following components were selected for the experiment: humus, nitrogen, mobile forms of potassium and nitrogen. Such plots include the plot, where soil sample I Reg. No. 388 was taken.

Table 3: Results of Analytical Research of the Soil Samples, collected in Ural Educational and Experimental Forest Farm.

\begin{tabular}{|c|c|c|c|c|c|c|c|}
\hline Measured parameter & RD for MP & $\begin{array}{c}\text { Unit of } \\
\text { measurement }\end{array}$ & $\begin{array}{c}\text { Sample I } \\
\text { Reg. No. } 388\end{array}$ & $\begin{array}{c}\text { Sample II } \\
\text { Reg. No. } 389\end{array}$ & $\begin{array}{c}\text { Sample III } \\
\text { Reg. No. } 390\end{array}$ & $\begin{array}{c}\text { Sample IV } \\
\text { Reg. No. } 391\end{array}$ & $\begin{array}{c}\text { Sample V } \\
\text { Reg. No. } 392\end{array}$ \\
\hline Hydrolytic acidity & GOST 26121-91 & $\mathrm{mmol} / 100 \mathrm{~g}$ & 1 & less than 17.1 & 13.1 & 36.7 & 25 \\
\hline $\begin{array}{l}\text { Organic substance } \\
\text { (humus) }\end{array}$ & GOST 26213-91 & $\%$ & 1.9 & 59.8 & 14.3 & 72.4 & 84.2 \\
\hline Exchange acidity & GOST 26484-85 & $\mathrm{mmol} / 100 \mathrm{~g}$ & less than 0.05 & 0.05 & 0.09 & 0.3 & 0.3 \\
\hline \multicolumn{8}{|c|}{ Gross content } \\
\hline Nitrogen & GOST 26107-84 & $\mathrm{mg} / \mathrm{kg}$ & 480 & 6,870 & 6,840 & 16,240 & 18,380 \\
\hline Phosphorus & \multirow{5}{*}{$\begin{array}{c}\text { CRDF } \\
\text { 16.1:2:3:3.11-98 }\end{array}$} & $\mathrm{mg} / \mathrm{kg}$ & 159 & 348 & 402 & 346 & 557 \\
\hline Potassium & & $\mathrm{mg} / \mathrm{kg}$ & 10,350 & 4,130 & 7,293 & 2,410 & 1,994 \\
\hline Sulfur & & $\mathrm{mg} / \mathrm{kg}$ & 363 & 2045 & 859 & 2,498 & 2,784 \\
\hline Cobalt & & $\mathrm{mg} / \mathrm{kg}$ & 8.1 & 7.9 & 11.8 & 4.3 & 3.6 \\
\hline Molybden & & $\mathrm{mg} / \mathrm{kg}$ & $<0.1$ & 1.5 & 0.1 & 1.2 & 1 \\
\hline \multicolumn{8}{|c|}{ Water extract analysis } \\
\hline Hydrogen index & GOST 26423-85 & $\mathrm{pH}$ units & 7.14 & 5.36 & 3.98 & 4.41 & 5.27 \\
\hline \multicolumn{8}{|c|}{ Mobile forms } \\
\hline Potassium & \multirow{4}{*}{$\begin{array}{c}\text { CRDF } \\
16.1: 2: 3: 3.50-08\end{array}$} & $\mathrm{mg} / \mathrm{kg}$ & 63 & 119 & 130 & 101 & 597 \\
\hline Phosphorus & & $\mathrm{mg} / \mathrm{kg}$ & 23 & 27 & 24 & 20 & 36 \\
\hline Calcium & & $\mathrm{mg} / \mathrm{kg}$ & 284 & 831 & 658 & 598 & 1,042 \\
\hline Magnesium & & $\mathrm{mg} / \mathrm{kg}$ & 55 & 122 & 84 & 87 & 143 \\
\hline
\end{tabular}

It is not recommended to mix the sewage sludge taken from different treatment facilities. The sewage sludge may be mixed with domestic fertilizers, such as turf. The following composite mixtures were prepared for the experiment:

a. A mixture of turf and sewage sludge (turd, sewage sludge and surplus activated spludge);

Sewage sledge treated with lime milk $\left(\mathrm{Ca}(\mathrm{OH})_{2}\right.$, sewage sludge and surplus activated spolud) - 8-10 years of storage;

b. Sewage sludge after the mechanic dehydration (sewage sludge and surplus activated sewage sludge) - fresh discharge;

c. Ash from the incineration of sewage sludge (sewage sludge and surplus activated sludge ash); d. A mixture of wastewater and surplus activated sludge1-2 years of storage;

e. A mixture of sewage sludge, surplus activated sludge and sewage sludge incineration sludge.

The preparation of such mixtures is based on the following assumptions.

a. Turf is rich in microelements, humus and nitrogen, but it also features a deficit of such components as potassium and phosphorus. Therefore, it was a rational decision to mix it with the sewage sludge.

b. The sewage sludge treated with lime milk. This type of waste is accumulated in many sludge lagoons located close to 
the treatment facilities. This type of waste is a large-tonnage waste that requires certain attention. The growing of seedlings in the forest nurseries increases the soils acidity because the plant roots excrete organic acids due to nitrogen-containing fertilizers that acidize the soil. Therefore, lime fertilizers are regularly used in the forest nurseries. Regular liming of the soil is performed in order to level the acid-basic balance and eliminate the factors inhibiting the plants' growth [18-20].

c. Sewage sludge after the mechanic dehydration (sewage sludge and surplus activated sewage sludge) - fresh discharge; this type of waste requires the search for modern methods of treatment as a large-tonnage waste of public treatment facilities.

d. Ash from the incineration of sewage sludge (sewage sludge and surplus activated sludge ash). This type of waste is produced both in the Russian Federation and in Europe, where the technologies of ash incineration in the oxidizing atmosphere are incinerated. Phosphorus is unique in the sense that it controls the metabolic process in the plants' organisms and at the same time serves an energy source for them. The deficit of natural phosphorus determines the needs of its full retrieval by the soil. e. The mixture of sewage sludge and surplus activated sludge -1-2 years of storage;ilt is a temporary deposited waste of the public treatment facilities for the preliminary dehydration and search for utilization methods ion the future.

The forest nurseries grow the stock for forest plantations (seedlings and springs of coniferous and certain deciduous plants). Seedlings mean the stock grown from the seeds of wood and bush species in a nursey's seedling division. The seedlings are grown for 1-5 years depending on the species, soil and climatic conditions. The quality of seedlings grown in the open soil and intended for growing forest plantations in the forest reserve lands and protection of forest plants are set out in the OSR (All-Union Standard) 56-9893. It is known that the key indicators of the quality of the grown planting stock, according to the statutory documents currently in effect, are the height of the surface part, length of the underground part (length of the rooting tuft) and diameter of the root collar. These indicators are decisive for the research about the impact of non-conventional fertilizers. The researches have shown that the types and doses of the fertilizers had a material impact on the dimensions of the grown planting stock. Thus, in Sukholozhsky Forest District forest nursery, three types of fertilizers used in the examined doses yielded a positive impact on the growth of the seedlings of the common pine of the second year of life (Table 4).

Table 4: Impact of Types and Doses of Non-Conventional Fertilizers on the Indicators of the Average Common Pine Seedling Height.

\begin{tabular}{|c|c|c|c|c|c|}
\hline & Type of fertilizer & Dose kg/ha & $\begin{array}{l}\text { Average stipitate } \\
\text { height, } \mathrm{cm}\end{array}$ & $\begin{array}{l}\text { Length of the rooting } \\
\text { tuft, } \mathrm{cm}\end{array}$ & $\begin{array}{l}\text { Average diameter, } \\
\text { mm }\end{array}$ \\
\hline \multicolumn{6}{|c|}{ Sukholozhsky Forest Nursery } \\
\hline \multicolumn{6}{|c|}{ Two-year seedlings } \\
\hline \multirow{2}{*}{1} & \multirow{2}{*}{ Mixture of turf and sewage sludge } & 500 & 14.4 & 17.1 & 2.6 \\
\hline & & 1,000 & 12.1 & 18.7 & 2.6 \\
\hline \multirow{2}{*}{2} & \multirow{2}{*}{$\begin{array}{l}\text { Sewage sludge treated with lime milk of } \\
\text { 8-10 years of deposition }\end{array}$} & 500 & 10.7 & 14 & 2 \\
\hline & & 1,000 & 10.6 & 18.7 & 2.3 \\
\hline \multirow{2}{*}{3} & \multirow{2}{*}{$\begin{array}{l}\text { Sewage sludge after the mechanic } \\
\text { dehydration - fresh discharge }\end{array}$} & 500 & 9.2 & 18.3 & 2.4 \\
\hline & & 1,000 & 10.6 & 21.5 & 2.4 \\
\hline \multirow{2}{*}{4} & \multirow{2}{*}{$\begin{array}{l}\text { Ash from the incineration of sewage } \\
\text { sludge }\end{array}$} & 500 & 13.8 & 16.1 & 2 \\
\hline & & 1,000 & 12.7 & 17.1 & 2.7 \\
\hline \multirow{2}{*}{5} & \multirow{2}{*}{$\begin{array}{l}\text { Mixture of sewage sludge and surplus } \\
\text { activated sludge - 1-2 years of storage }\end{array}$} & 500 & 9.2 & 19.7 & 2.5 \\
\hline & & 1,000 & 12.5 & 20.4 & 2.8 \\
\hline \multirow[b]{2}{*}{6} & \multirow{2}{*}{$\begin{array}{l}\text { Mixture of sewage sludge, surplus } \\
\text { activated sludge and sewage sludge } \\
\text { incineration ash. }\end{array}$} & 500 & 19.1 & 19.3 & 3.6 \\
\hline & & 1,000 & 11.7 & 23.3 & 2.1 \\
\hline 7 & Control (no fertilizers) & - & 11.5 & 18.6 & 2.7 \\
\hline \multicolumn{6}{|c|}{ One-year seedlings } \\
\hline \multirow{2}{*}{1} & \multirow{2}{*}{ Mixture of turf and sewage sludge } & 500 & 6.4 & 12.4 & 0.7 \\
\hline & & 1,000 & 6.2 & 6.5 & 0.9 \\
\hline \multirow{2}{*}{2} & \multirow{2}{*}{$\begin{array}{l}\text { Sewage sludge treated with lime milk of } \\
8-10 \text { years of deposition }\end{array}$} & 500 & 6.8 & 11.7 & 0.7 \\
\hline & & 1,000 & 5.9 & 6.9 & 0.6 \\
\hline \multirow{2}{*}{3} & \multirow{2}{*}{$\begin{array}{l}\text { Sewage sludge after the mechanic } \\
\text { dehydration - fresh discharge }\end{array}$} & 500 & 6 & 10.5 & 0.7 \\
\hline & & 1,000 & 5.1 & 6.9 & 0.7 \\
\hline \multirow{2}{*}{4} & \multirow{2}{*}{$\begin{array}{l}\text { Ash from the incineration of sewage } \\
\text { sludge }\end{array}$} & 500 & 6.6 & 14.1 & 1.1 \\
\hline & & 1,000 & 6.4 & 7.6 & 1.1 \\
\hline
\end{tabular}




\begin{tabular}{|c|c|c|c|c|c|}
\hline \multirow{2}{*}{5} & \multirow{2}{*}{$\begin{array}{l}\text { Mixture of sewage sludge and surplus } \\
\text { activated sludge - 1-2 years of storage }\end{array}$} & 500 & 7 & 12.1 & 0.9 \\
\hline & & 1,000 & 6.1 & 11.2 & 1.3 \\
\hline \multirow{2}{*}{6} & \multirow{2}{*}{$\begin{array}{l}\text { Mixture of sewage sludge, surplus } \\
\text { activated sludge and sewage sludge } \\
\text { incineration ash. }\end{array}$} & 500 & 6.5 & 12.3 & 0.9 \\
\hline & & 1,000 & 6.3 & 10 & 0.8 \\
\hline 7 & Control (no fertilizers) & - & 5.8 & 14.3 & 0.8 \\
\hline \multicolumn{6}{|c|}{ Ural Educational and Experimental Forest Farm } \\
\hline \multicolumn{6}{|c|}{ Two-year seedlings } \\
\hline \multirow{2}{*}{1} & \multirow{2}{*}{ Mixture of turf and sewage sludge } & 500 & 10.8 & 17.7 & 2.6 \\
\hline & & 1,000 & 12.4 & 16.5 & 2.6 \\
\hline \multirow{2}{*}{2} & \multirow{2}{*}{$\begin{array}{l}\text { Sewage sludge treated with lime milk of } \\
\text { 8-10 years of deposition }\end{array}$} & 500 & 12.8 & 18.9 & 2 \\
\hline & & 1,000 & 13.1 & 16.5 & 2.3 \\
\hline \multirow{2}{*}{3} & \multirow{2}{*}{$\begin{array}{l}\text { Sewage sludge after the mechanic } \\
\text { dehydration - fresh discharge }\end{array}$} & 500 & 11.5 & 17.3 & 2.4 \\
\hline & & 1,000 & 15.3 & 15.1 & 2.4 \\
\hline \multirow{2}{*}{4} & \multirow{2}{*}{$\begin{array}{l}\text { Ash from the incineration of sewage } \\
\text { sludge }\end{array}$} & 500 & 10.2 & 23 & 2.7 \\
\hline & & 1,000 & 12.4 & 11.3 & 2.1 \\
\hline \multirow{2}{*}{5} & \multirow{2}{*}{$\begin{array}{l}\text { Mixture of sewage sludge and surplus } \\
\text { activated sludge - 1-2 years of storage }\end{array}$} & 500 & 12.4 & 22.1 & 2.5 \\
\hline & & 1,000 & 18.8 & 15.8 & 2.8 \\
\hline \multirow{2}{*}{6} & \multirow{2}{*}{$\begin{array}{l}\text { Mixture of sewage sludge, surplus } \\
\text { activated sludge and sewage sludge } \\
\text { incineration ash }\end{array}$} & 500 & 13.7 & 22.3 & 3.6 \\
\hline & & 1,000 & 14.3 & 14.9 & 2.1 \\
\hline 7 & Control (no fertilizers) & - & 16 & 19.1 & 2.7 \\
\hline \multicolumn{6}{|c|}{ One-year seedlings } \\
\hline \multirow{2}{*}{1} & \multirow{2}{*}{ Mixture of turf and sewage sludge } & 500 & 5.8 & 14.5 & 0.7 \\
\hline & & 1,000 & 3.8 & 11.1 & 0.9 \\
\hline \multirow{2}{*}{2} & \multirow{2}{*}{$\begin{array}{l}\text { Sewage sludge treated with lime milk of } \\
\text { 8-10 years of deposition }\end{array}$} & 500 & 6 & 13 & 0.7 \\
\hline & & 1,000 & 2.3 & 14.3 & 0.6 \\
\hline \multirow{2}{*}{3} & \multirow{2}{*}{$\begin{array}{l}\text { Sewage sludge after the mechanic } \\
\text { dehydration - fresh discharge }\end{array}$} & 500 & 6.1 & 13.3 & 0.7 \\
\hline & & 1,000 & 6.7 & 15.6 & 0.7 \\
\hline \multirow{2}{*}{4} & \multirow{2}{*}{$\begin{array}{l}\text { Ash from the incineration of sewage } \\
\text { sludge }\end{array}$} & 500 & 4.4 & 17.3 & 1.1 \\
\hline & & 1,000 & 6.7 & 15.6 & 1.1 \\
\hline \multirow{2}{*}{5} & \multirow{2}{*}{$\begin{array}{l}\text { Mixture of sewage sludge and surplus } \\
\text { activated sludge }-1-2 \text { years of storage }\end{array}$} & 500 & 4.4 & 16.4 & 0.9 \\
\hline & & 1,000 & 7.6 & 16.2 & 1.3 \\
\hline & Mixture of sewage sludge, surplus & 500 & 5.3 & 11.4 & 0.9 \\
\hline 6 & $\begin{array}{l}\text { activated sludge and sewage sludge } \\
\text { incineration ash }\end{array}$ & 1,000 & 5.2 & 16.4 & 0.8 \\
\hline 7 & Control (no fertilizers) & - & 4.1 & 14.5 & 0.8 \\
\hline
\end{tabular}

Especially some elements have a material impact on the growth and total mass of underground parts. Nitrogen as the key element of nutrition in the life of plants determines to the greatest extent the growth of underground organs of the majority of species, through its impact on the surface parts is more material. The role of phosphorus in most cases is much weaker, and it has an equal effect on the development of both underground and surface organs. As concerns its impact on the root morphology, it should be noted that phosphorus inhibits the growth of roots of the majority of plants and promotes branching. The effect of potassium is identical to that of phosphorus. In the environment poor in potassium the root system degenerates. For example, the summer barley features a complete deadening of the root tissues in case of potassium deficit as soon as the stage of milky ripeness. Calcium and magnesium promote better branching of the roots, while their deficit inhibits the cells division in the apical meristem, resulting in the slowdown of roots lengthwise growth. The key results may be traced based on the information provided in Table 4. If we consider Sukholozhsky Forest Nursery, the best results across all the indicators were obtained in two-year seedlings with the applied dose of 1,000 kg/ ha. The best indicators in terms of surface part length, subsurface part length (rooting tuft length) and diameter of root collar were obtained for the following composite mixtures 1, 2, 3, 4, 5 and 6. Quite good results were obtained for the sewage sludge treated with lime milk after 8-10 years of storage. For one-year seedlings, the optimal results were obtained if the applied dose of composite fertilizers amounted to $500 \mathrm{~kg} / \mathrm{ha}$.

The following composite mixtures provided the best effect: 4, 5 and 6. Quite good indicators were obtained in case of using composite mixtures 1,2 and 3 . The difference in the fertilizer 
doses can be explained by the nutritional elements consumed by the seedlings. In case of excessive nutrition with the (nitrogencontaining) fertilizer, the quantity of non-protein nitrogen in the plant increases, and the growth of the seedlings is inhibited. The dose of $1,000 \mathrm{mg} / \mathrm{kg}$ does not have a material impact on the key indicator of the quality of planting stock - one-year seedlings, and somewhat inhibits their development. The situation with the two-year seedlings is different. If we consider Ural Educational and Experimental Forest Farm, the best results across all the key indicators were obtained in two-year seedlings with the applied dose of $500 \mathrm{~kg} / \mathrm{ha}$. The best indicators in terms of surface part length, underground part length (rooting tuft length) and diameter of root collar were obtained for the following composite mixtures: 4, 5 and 6. For one-year seedling, the optimal results were obtained if the applied dose of composite fertilizers amounted to $500-$ $1,000 \mathrm{~kg} / \mathrm{ha}$. The following composite mixtures provided the best effect: 1, 4, 5 and 6 . It should be noted that the information in Table 4 confirms that the application of the examined mixtures provided for more intensive growth of the second-year seedlings as compared to the control specimen. Significantly better results were obtained with the use of non-conventional fertilizers in the first-year seedlings. Especially effective were the fertilizers applied in the dose of $500 \mathrm{~kg} / \mathrm{ha}$. The majority of tested non-conventional fertilizers had a positive impact on the growth of roots of the common pine seedlings both of the second and the first year see (Table 4). The second-year seedlings are characterized by the highest average height after the use of composite mixtures in the amount of $1,000 \mathrm{~kg} / \mathrm{ha}$.

\section{Conclusion}

In the process of the seedlings' growth, the changes in the chemical properties of the substrate occur with the use of nutrients due to consumption by the seedlings' root systems. Also, in case of intensive watering, a part of the nutrients is washed out from the substrate. The presence of nutrients in the forms available to the plants plays an important role in the growing of the planting stock. In addition to the mineral fertilizers, it is necessary to use the organic component to improve the soil structure. In this regard, the use of non-conventional fertilizers - the composite mixtures containing mineral and organic components is in demand by the forest nurseries. The authors have substantiated the choice of component analysis of the prepared composite mixtures based on the sewage sludge produced by public wastewater treatment facilities.

The performed research allows to conclude that all the composite mixtures have a positive impact on the key indicators of the planting stock quality. The optimal doses for one-year seedlings is $500 \mathrm{~kg} / \mathrm{ha}$, and for tow-year seedlings $-1,000 \mathrm{~kg} / \mathrm{ha}$.
2. Wagner KH (1973) Gefährliche Stoffe in Bodenverbesserung smitteln. Naturwissens chasten60: 160-161.

3. Modig S Harte (1991) Auflagen. Seconder Roust 8(12): 370-376.

4. Rudolph R (1990) Auswirkungen der Klärschlammverbrennung auf die Umwelt (Suburblike). Müll und Abfall 22(8): 481-489.

5. Aleksandr Nikolaevich (2009) Methods of Disinvasion of Wastewater and their Sewage Sludge in the Central Black Earth Region (on the example of Kursk Oblast). Thesis and Abstract, Higher Attestation Commission of the Russian Federation Candidate of Biological Sciences Borzenkov.

6. Drozd GYa (2014) Utilization of Mineralized Wastewater Sludge: Issues and Solutions. Guide of an Environmental Specialist 4: 84-96.

7. Bolzonella A, Cavinato C Fatone (2012) High rate mesophilic, thermophilic, and temperature phased anaerobic digestion of waste activated sludge: A pilot scale study. Waste Management 32(6): 11961201.

8. Kolesnikov BP Forest Growing Terms and Forest types of Sverdlovsk Oblast. Ural Research Centre of the USSR Academy of Sciences, pp. 190197.

9. Sokolov AV (1967) Development of Schemes for Experiments with Fertilizers. Methodology of Field and Vegetation Experiments with Fertilizers and Herbicides. pp. 139-146.

10. Scherba SV (1967) Methodology of Field Experiment with Fertilizers. Methodology of Field and Vegetation Experiments with Fertilizers and Herbicides, p. 3-69.

11. Mattis GYa (1978) Theory and Practice of Accelerated Growing of Seedlings in the Forest Nurseries. Annals of Agricultural Science 11: 109-114.

12. Morozova EV, Iozus AP, Zelenyak AK (2014) Use of Regression Analysis in Studying the Impact of Heat Supply on the Growth and Development of Seedlings of the Common Pine in the Forest Nurseries. Fundamental Research 11(8): 1736-1739.

13. Novoseltseva AI, Smirnov NA (1983) Guide to Forest Nurseries. Moscow: Forest Industry, pp. 280.

14. Romanov EM (2000) Growing the Seedlings of Wood Plants: Bioecological and Agrotechnical Aspects. Ioshkar-Ola: MarGTU, pp. 500.

15. Sinnikov AS, Mochalov BA, Drachkov VN (1986) Growing the Seedlings of Coniferous Species in Polyethylene Greenhouses. Moscow: Agropromizdat, pp. 100-126.

16. Morozova EV, Iozus AP (2016) Specifics of Chemical Composition of OneYear Pine Seedlings Grown in the Steppe Zone. Forest Nurseries: Success of Modern Natural Sciences 12(1): 94-98.

17. Kramer PD, Kozlovsky TT (1983) Physiology of Woody Plants. Moscow: Forest Industry, pp. 464.

18. Pobedov VS (1977) Guide to the Use of Fertilizers in Forest Management. Moscow: Forest Industry pp: 184

19. Yurenya AV (2009) Methods of Selecting the Mean Sample for Analyzing Acidity and Humus in sod and podsol soils, Materials of BGTU. Series 1, Forest Industry Issue 17: 221-222.

20. Tueva OF (1966) Phosphorus in Plant Nutrition. Moscow: Science, pp. 296.

\section{References}

1. http://ecopress.center/page3688015.html 


\section{(c) (i)}

This work is licensed under Creative

Commons Attribution 4.0 License

To Submit Your Article Click Here: Submit Article

DOI: $10.32474 /$ CIACR.2019.07.000260

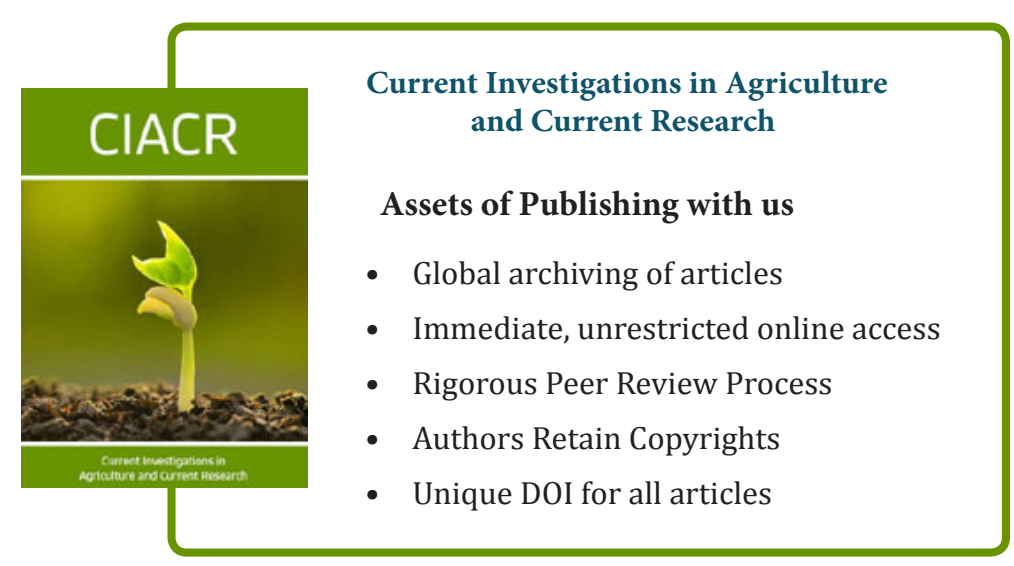

